\title{
The credit-output relationship during the recovery from recession
}

\author{
Fabrizio Coricelli · Marco Frigerio
}

February, 122015

\begin{abstract}
The Great Recession has generated renewed interest in the phenomenon of creditless recoveries. This paper studies the mechanisms behind such phenomenon, analyzing data on industries for a large set of countries over a forty year period from 1963 to 2003. We find that during creditless recoveries there is a significant reallocation of resources away from sectors that are more dependent on bank credit, both for their investments and for their short-term liquidity needs. The adverse effects of credit constraints are softened in sectors that rely more on alternative sources of financing, such as trade credit, or in sectors that have more favorable access to credit because of higher collateral. We thus conclude that creditless recoveries do not simply reflect a natural process of deleveraging, but they may imply significant inefficiencies in the allocation of resources.
\end{abstract}

Keywords Creditless recoveries, financial crises, bank credit vs trade credit

JEL Classifications E32, G01

F. Coricelli (Corresponding author), Paris School of Economics and CEPR; · M. Frigerio, IMT Institute for Advanced Studies Lucca. 


\section{Introduction}

The global financial crisis that started in 2007 has generated renewed interest in the role of credit in shaping economic recoveries and in particular in creditless recoveries. In their seminal contributions, Calvo et al (2006a,b) coined the term Phoenix Miracles to describe a phenomenon whereby after systemic crises economic activity recovers without an accompanying recovery in credit. The phenomenon has been mainly documented in emerging economies, but seems to play a role in industrial countries as well. Indeed, Calvo and Loo-Kung (2010) argue that the subprime crisis shares several characteristics of Phoenix Miracles. Reinhart and Rogoff (2009) have also drawn a parallel between the recent financial crisis and episodes of systemic crises in emerging markets, which are typically characterized by creditless recoveries. Takáts and Upper (2013) show that, in case of financial crises preceded by credit booms, deleveraging does not impede GDP recovery.

A main concern associated with creditless recoveries is that, even though they often imply a rapid recovery of previous output levels, they may be inefficient as they may lead to lower long-run growth. One reason for such adverse effect is that during creditless recoveries resources shift away from more to less credit intensive activities. A reallocation based on credit intensity of production may not reflect an efficient allocation of resources, as more credit-dependent activities may in fact be characterized by higher productivity growth. This is the case, for instance, when credit finances investments in both physical and human capital and technological innovation (see Gorodnichenko and Schnitzer (2013)).

Several explanations of creditless recoveries have been proposed in the literature. Calvo et al (2006a,b) argue that a sudden underutilization of capacity created by a crisis episode can rationalize a fast creditless recovery. Indeed, it appears that investment recovers much more slowly than GDP after systemic crises, suggesting that the recovery mainly takes place through the absorption of unused capacity. As investment is assumed to be a credit-intensive activity, lack of investment during recovery may explain why the recovery appears creditless.

Claessens et al (2009) suggest two additional explanations. First, creditless recoveries may be explained by a substitution between bank credit and other sources of financing such as trade credit or internal finance. This substitution may lead to the observation of creditless recoveries when credit is measured as bank credit. Second, creditless recoveries may be associated with a process of reallocation from more to less credit-intensive sectors. Finally, there is a view that challenges the existence of creditless recoveries, defining them as an artifact due to an incorrect choice of the relevant credit variable, namely the stock of credit rather than the flow of credit (Biggs et al $(2009,2010))$. According to Biggs et al $(2009,2010)$, if one considers the flow of credit, GDP and credit would always move in tandem. This view can be considered as an "impossibility" hypothesis, which we will properly test in the paper.

Existing literature has mainly documented the existence of creditless recoveries and illustrated the main features of such recoveries, focusing both on the behavior of main macroeconomic variables and the asymmetric behavior across sectors (Abiad et al (2011)). However, the main mechanisms at work during creditless recoveries have not been sufficiently investigated. This is the gap this paper tries to fill, 
complementing existing literature in three main dimensions. ${ }^{1}$ First, differently from Abiad et al (2011), we focus on recoveries from recessions, defined as negative GDP changes, rather than output gaps. Second, we analyze two types of creditless recoveries, one associated to lack of recovery in credit stocks (Calvo type), and the other associated to lack of recovery in credit flows (Biggs type). Finally, and most important, in addition to the reduction of the needs for financing investments, we analyze the reduction of the needs for bank financing of working capital, emphasizing two potential mechanisms. First, the substitutability between bank credit and trade credit, and, second, the reduction of working capital needs, through a shortening of the "cash conversion cycle."

Following the identification strategy of Rajan and Zingales (1998) (RZ from now on $)^{2}$, our identification of the impact of creditless recoveries on output is based on the interaction between financial characteristics of industrial sectors and the rate of contraction of private credit at the country level during recovery episodes. In addition to the RZ indicator of external financial dependence, we analyze several other sectoral characteristics that are related more to working capital than to investment financing.

The main findings of the paper are as follows.

First, we find that industries that are more dependent on external finance recover more slowly when recoveries are classified as creditless. This result is even stronger when we consider a measure of short-term dependence on external finance, such as the sectoral liquidity needs introduced in Raddatz (2006). Second, we find that during the recovery sectors with greater capability of mobilizing collateral perform better. These are the sectors with higher tangibility of assets and with a higher capital intensity of production. Finally, we find evidence that industries more dependent on trade credit tend to recover more quickly. At the industry level, indeed, a lower dependence on bank credit relative to trade credit is associated with a better output performance during the peak-to-recovery episode, especially when the recovery is creditless ( $s u b$ stitution effect). At the country level, by contrast, a higher dependence on trade credit relative to bank credit appears to have a negative impact on growth during recoveries. This suggests the existence of a propagation of financial distress through trade credit chains during crisis episodes (contagion effect).

Interestingly, the above results only apply to emerging economies, while they are generally insignificant in developed economies. One main reason that may explain such a difference across country groups is due to the higher level of development of financial markets in developed economies. Indeed, when creditless recoveries are the consequence of credit impairment, industries dependent on external finance may still recover in developed countries thanks to an easier substitutability among alternative sources of financing, such as corporate bonds and equity. However, we can speculate that during the Great Recession ${ }^{3}$ developed economies are likely to have performed similarly to emerging economies in previous crises, as the financial shock has affected all segments of financial markets.

\footnotetext{
1 This paper draws from previous analysis of Coricelli and Roland (2011), but the definition of creditless recoveries and the econometric analysis are different.

2 See also Levine (2005) for a general review of methods used in the literature on the nexus between finance and growth.

3 Recall that our sample excludes the recent Great recession.
} 
The paper is structured as follows. Section 2 discusses the different definitions of creditless recoveries and presents some stylized facts, including the occurrence of such phenomena in the aftermath of the last global financial crisis. Section 3 discusses possible interpretations of creditless recoveries and reviews the relevant literature. Section 4 contains the empirical analysis. It first presents summary indicators of the extent of reallocation across sectors during creditless and credit-with recoveries, and then describes the estimated equations, the data sources, the different samples used in the econometric analysis and, finally, the main results. Sections 5 addresses potential endogeneity concerns and the robustness of our regression analysis. Section 6 concludes and discusses avenues for further research.

\section{Creditless recoveries: definition, measurement and stylized facts}

The notion of creditless recovery is subject to debate. For instance, Biggs et al (2009, 2010) claim that creditless recoveries à la Calvo are unlikely to exist, as they are based on the use of an inappropriate measure of credit, namely the stock of credit, instead of the more relevant flow of credit. They argue that some recoveries may artificially appear creditless when one compares developments in the stock of credit to developments in GDP, which is a flow variable. Assuming that changes in GDP strongly depend on investments that are financed by new borrowing, they find that during recoveries previously identified as creditless the rebound in economic activity is highly correlated with the rebound in the flow of credit, even if it is poorly correlated with the growth in its stock.

The analysis by Biggs et al $(2009,2010)$ does not necessarily contradict the results by Calvo et al (2006a,b), but rather offers a different, possibly complementary, approach to study the role of credit conditions in shaping economic recoveries. Indeed, Biggs et al $(2009,2010)$ underline the role of credit flows for financing new net investments and thus GDP growth. However, following crises, GDP recovers at least partly by using idle capacity, without the need for new investments. Therefore, recoveries during which the stock or the flow of credit fail to recover may be two distinct phenomena.

Moreover, a large share of credit is short-term and finances working capital rather than investment. In such a case, the distinction between flows and stocks is blurred.

For these reasons, in this paper we analyze both types of creditless recoveries. We conduct our analysis on episodes of recession and subsequent recovery concerning all countries with available data in the UNIDO dataset, since the main empirical analyses will be conducted at the sectoral level. ${ }^{4}$ The whole sample contains 421 episodes in 143 countries (see Appendix A for further details).

\footnotetext{
${ }^{4}$ See paragraph 4.3 .
} 


\subsection{How common are creditless recoveries?}

In this section we investigate the frequency of creditless recoveries, both for the cases during which the stock of credit fails to increase (Calvo sense) and those during which the flow of credit (Biggs sense) fails to increase.

First, we investigate the evolution of the stock of credit during episodes of recovery ( $\Delta$ Stock) by looking at the change in real credit per capita from output peak to full recovery point. ${ }^{5}$ We interpret a negative difference as indicating the presence of a creditless recovery at the country level in the Calvo sense, namely a recovery in GDP per capita to pre-downturn level that is not accompanied by a corresponding pick up in credit per capita.

In about 62 percent of the recoveries, defined with-credit recoveries, real credit per capita increases on average by 21.3 percent from output peak to full recovery point. In the remaining 38 percent of recoveries, defined creditless, real credit per capita decreases on average by 14.5 percent from peak to recovery point. The average decline in GDP per capita is 2.2 percent during recessions that precede with-credit recoveries and 3.8 percent during those preceding creditless recoveries. The average duration of peak-to-recovery episodes is also higher in case of creditless recoveries (3.16 years) than in case of with-credit recoveries ( 2.74 years).

Second, we investigate the evolution of the flow of credit during episodes of recovery by looking at the difference between the growth rate of real credit per capita in the recovery year and in the peak year of each episode $(\Delta F l o w)$. When this difference is negative we define the episode as a creditless recovery in the Biggs sense. In our sample, the growth rate of credit per capita increases in about 45.6 percent of the episodes. During with-credit recoveries à la Biggs, the growth rate of credit per capita increases by an average of 12 percentage points from output peak to full recovery point. In the remaining 54.4 percent of the episodes, defined as creditless recoveries à la Biggs, the growth rate of real credit per capita decreases on average by 14.8 percentage points.

Therefore, creditless recoveries cannot be ruled out even when one focuses on the flow of credit rather than on the stock of credit as suggested by Biggs et al (2009, $2010)$. As a result, the "impossibility" hypothesis of Biggs et al $(2009,2010)$ is not supported by empirical evidence. The average decline in GDP per capita is 2.6 percent during recessions that precede with-credit recoveries à la Biggs and 2.9 percent during those preceding creditless recoveries. Even under this definition, the average duration of peak-to-recovery episodes is still higher in creditless recoveries $(2.99$ years) than in with-credit recoveries (2.75 years), though the difference is less pronounced than in the case of creditless recoveries $a$ la Calvo.

In summary, creditless recoveries are not a rare phenomenon, either in Calvo or in Biggs sense. In addition, our descriptive statistics show that a failure of credit to recover typically follows larger drops in GDP per capita. Indeed, creditless recoveries may be explained, at least in part, with a bounce-back effect. This is also in line with the view expressed in Calvo et al (2006a) that

\footnotetext{
5 Real credit per capita is obtained multiplying Domestic credit to private sector by banks in percent of $G D P$ and GDP per capita in constant LCU (local currency units). Both measures are taken from the WDI dataset of the World Bank.
} 
"Phoenix Miracle-type recoveries are highly suggestive of sudden underutilization of capacity. This is so, because after large drops in output, it would be difficult to rationalize speedy post-collapse recovery, unless idle resources are part of the equation."

Table 1 shows statistics on the occurrence of creditless recoveries in the Calvo and Biggs sense for country clusters. ${ }^{6}$ Table 1 shows that the decline in GDP per capita is consistently higher during recessions that precede creditless recoveries in the Calvo sense rather than during recoveries with credit. This is true across all country categories. However, creditless recoveries in the Calvo sense are more frequent in emerging economies (EM) than in developed economies (DM). Furthermore, on average, during recession phases GDP per capita falls by less in DM than in EM.

In contrast, creditless recoveries in the Biggs sense are almost as frequent in DM as in EM. Even differences in output decline during the recession phase and differences across the two groups of countries in credit recovery are less pronounced, suggesting that creditless recoveries à la Biggs are not primarily an emerging market phenomenon.

(Insert Table 1 here)

\subsection{Creditless recoveries and the global financial crisis}

The findings in this paper are also relevant for the dynamics of the global economy in the aftermath of the global financial crisis. As reported in Table 2, we identify 54 recession episodes affecting the countries within our sample since 2007. In cases of double-dip recessions, we consider only the first peak-to-recovery episode if real GDP per capita goes back to the pre-crisis peak. Otherwise, we extend the recession episode to include the new downturn, so that it becomes part of the same episode.

For comparability with our analysis on previous recessions, we focus on FullRecovery episodes, i.e. episodes in which GDP per capita goes back to the pre-crisis peak by 2013 (the last year with definitive data for GDP and bank credit). Table 2 shows that in EM the proportion of Full-Recovery episodes is higher than in DM and the duration of the peak-to-recovery period is shorter, notwithstanding a similar fall in GDP per capita (slightly smaller than 4 percent) during the recession phase.

By contrast, Missed-Recovery episodes are those recession episodes in which at the end of 2013 real GDP per capita is still lower than at the pre-crisis peak. These episodes are also characterized by larger falls in GDP during the recession phase. In 2013, many economies within this group are still in recession or in an early stage of recovery.

(Insert Table 2 here)

\footnotetext{
${ }^{6}$ For details on country classification see Appendix A
} 
Let us now turn to the behavior of bank credit during Full-Recovery episodes after the global financial crisis.

Table 3 shows that following the Great Recession, in contrast with historical evidence, creditless recoveries in the Calvo sense are more frequent in DM (33 percent) than in EM (24 percent). However, only in EM the decline in real GDP per capita is higher during recessions that precede creditless recoveries rather than during those preceding recoveries with credit. No significant differences exist in DM.

In contrast, when we look at creditless recoveries in the Biggs sense, we find that they are much more frequent in EM (62 percent) than in DM (33 percent). Moreover, when the recovery is creditless in the Biggs sense, credit weakness is remarkably higher in EM than in DM. Therefore, in the aftermath of the last crisis, creditless recoveries à la Biggs seem to be particularly relevant in EM.

(Insert Table 3 here)

\subsection{Creditless recoveries and banking crises}

It is conceivable that the emergence of creditless recoveries depends on the nature of the peak-to-recovery episode. We therefore investigate the characteristics of recoveries depending on whether they coincide with a systemic banking crisis, identified by Reinhart and Rogoff (2009) ${ }^{7}$ and match them to our data set. Therefore, our banking crisis dummy takes the value of one for the episodes in which there is a banking crisis event during the peak-to-recovery years, and zero otherwise.

According to this definition, in our sample 57.1 percent of the episodes classified as banking crises are associated with creditless recoveries in the Calvo sense, while only 25.4 percent of the other episodes are associated with creditless recoveries. If we look at creditless recoveries in the Biggs sense, the same shares become respectively 61.9 and 43.7 percent. Table 4 summarizes the characteristics of recoveries depending on the nature of the crisis. It is apparent that banking crises tend to be associated with larger output declines in the recession period and negative changes of credit stocks and flows in the peak-to-recovery years. This provides some evidence that creditless recoveries tend to be associated to episodes of prolonged/systemic credit market disruptions.

\section{(Insert Table 4 here)}

\footnotetext{
7 The authors define banking crises according to two types of events: "(1) bank runs that lead to the closure, merging or takeover by the public sector of one or more financial institutions; (2) if there are no runs, the closure, merging, takeover or large-scale government assistance of an important financial institution (or group of institutions) that marks the start of a string of similar outcomes for other financial institutions"
} 


\section{Interpreting creditless recoveries}

Creditless recoveries can in principle reflect highly heterogeneous experiences. For instance, GDP can recover without an accompanying increase in credit because growth is driven by components of aggregate demand that are less credit-intensive than others. On the supply side, firms can increase output levels by simply using their spare capacity. If this is the case, creditless recoveries are not a consequence of credit impairment. Credit remains low because it is not strictly needed.

However, creditless recoveries may in fact reflect persisting problems in the supply of credit by the banking sector. If this is the case, we can think about several determinants contributing to the recovery.

First, firms can recover by relying on alternative sources of funding, such as operating cash flows (internal financing) or trade credit.

Secondly, the recovery can be driven by shifts in the allocation of financial resources. If credit is needed to restore working capital, firms can cut back on longterm investments in physical capital. Calvo et al (2006a,b) suggest that this could be a suitable justification for creditless recoveries in EM after systemic sudden stop episodes.

Finally, a more efficient and aggressive policy in terms of working capital management at the firm level can explain a creditless recovery. Indeed, production may increase because firms are able to sustain higher level of operating expenses without increasing their working capital. Moreover, firms can draw down their stocks of intermediate goods to sustain production. This is similar to the mechanism associated to the increase in the utilization of capital. Both mechanisms can be sustained only for a limited amount of time, until utilization of capital is restored and the inventories of intermediate goods have been exhausted.

All the mechanisms discussed above may play a role during creditless recoveries, and the empirical analysis is meant to assess their relative importance.

\subsection{Related literature}

The seminal work by Calvo et al (2006a,b), and the recent global financial crisis, has spurred several papers on creditless recoveries.

Two papers are closely related to ours. One is Kannan (2012), who uses the same industrial dataset we use to analyze the sectoral response to financial crises. Kannan (2012) concludes that sectors with higher financial dependence in the RZ sense display slower recoveries in the aftermath of financial crises. The main difference between our analysis and Kannan (2012) is that we analyze the dynamics in creditless recoveries and not recoveries from financial crises.

The second paper, perhaps the closest to our analysis is Abiad et al (2011). Using aggregate and sectoral data, the authors find that average growth during creditless recoveries, defined as recoveries during which the growth rate of real bank credit is zero or negative, is about a third lower than during normal recoveries. In addition, sectors that are more dependent on external finance are found to grow relatively less 
during creditless recoveries. The authors conclude that creditless recoveries reflect impaired financial intermediation.

Despite the common theme of creditless recoveries, our paper differs from Abiad et al (2011) in three main dimensions. First, we focus on recoveries from recessions, whereas Abiad et al (2011) focus on recoveries from episodes of negative output gaps. One main reason for focusing on recessions rather than negative output gaps is that the notion of output gap can markedly vary when comparing advanced and emerging economies, as effectively stressed by Aguiar and Gopinath (2007). The definition of recovery is also different depending on whether one uses output gaps or output levels. With output gaps, recovery implies a return to the trend, whereas with output levels, recovery implies return to the pre-recession level. One problem with defining recovery as the return to trend is that, as emphasized by Cerra and Saxena (2008), deep recessions, especially when associated to financial crises, tend to affect the trend as well. With a changing trend, it is unclear what is the meaning of recovery as "return to trend."

Second, we analyze two different types of creditless recoveries, the Calvo and Biggs types.

Third, whereas Abiad et al (2011) investigate the negative impact of prolonged tight bank credit conditions on growth during recovery, we also focus on the ability of firms to recover by substituting trade credit for bank credit, or by reducing their working capital needs. Our empirical specifications reflect this conceptual difference. In addition to the RZ indicator of external finance dependence, we use indicators more related to working capital financing and to the relative reliance on trade versus bank credit. In summary, we add to Abiad et al (2011) an explicit analysis of the mechanisms behind creditless recoveries.

\section{Empirical analysis}

In this section, we explore the link between creditless recoveries and growth by asking whether industries that are relatively more dependent on external finance have a worse relative performance when recoveries are classified as creditless. We first report descriptive statistics on the reallocation process and then move to the econometric analysis.

\subsection{Reallocation during creditless recoveries}

Using sectoral data we can identify the reallocation of resources towards sectors that are less dependent on external finance or, more generally, less subject to the effects of tightening conditions in credit markets. Lower exposure to credit tightness can arise either because of the ability to pledge higher collateral, or because of the ability to substitute bank credit with alternative sources of financing, such as trade credit.

Before carrying out the econometric analysis, it is useful to present summary indicators of such potential reallocation process. We present evidence for both types of creditless recoveries, Calvo and Biggs types. 
Table 5 contains the results. We have computed summary indicators at the country level as weighted averages of each indicator of financial exposure, with weights given by the share of each sector in total value added. We computed such indicators at the pre-recession peak and at the recovery point. We interpret the changes of the indicators from the peak to recovery points as a measure of reallocation. Using external dependence as an example, we derive the synthetic index at a point $t$ as follows:

$$
\text { CountryDep }_{c, t}=\sum_{s, t}\left(\frac{V A_{s, c, t}}{\sum_{s} V A_{s, c, t}}\right) \text { ExtDep }_{s}
$$

where $s$ denotes the industry and $c$ identifies the individual country. $V A$ is the value added at the sectoral level and ExtDep is the dependence on external finance at the sectoral level. For each peak-to-recovery episode in our extended sample, we compute this synthetic index in both the peak year and the recovery year. We also report the synthetic index for the following indicators: dependence on short-term credit, as summarized by the time elapsed between the moment a firm pays for its inputs until it is paid for the goods it sells ("Cash Conversion Cycle"), asset tangibility and relative dependence on bank vs. trade credit.

In Table 5, we report the average values obtained by income group (developed countries vs. emerging markets) and by type of recovery (credit-with vs. creditless).

\section{(Insert Table 5 here)}

Two main facts stand out. First, the synthetic index of dependence on external finance is significantly higher in DM than in EM. This result is consistent with Rajan and Zingales (1998), according to which sectors more dependent on external finance grow faster in countries with higher financial development. Second, during peakto-recovery episodes, the average synthetic index decreases only in EM, both for creditless recovery in the Calvo and in the Biggs sense.

This suggests that the reallocation effect due to creditless recoveries is more likely to be relevant in EM than in DM.

Similar results are obtained when we look at the dependence on working capital credit (proxied by the cash conversion cycle), at asset tangibility, and at the relative dependence on bank versus trade credit. For these indicators the main reallocation seems to occur during Calvo-type creditless recoveries.

In summary, there is prima facie evidence that one channel behind creditless recoveries is associated to the reallocation of resources among sectors with different characteristics. In the econometric analysis contained in the next sections, we verify whether such reallocation effects are statistically significant in describing specific mechanisms characterizing creditless vs. credit-with recoveries.

\subsection{Econometric analysis}

We use a difference-in-differences approach to identify causal links between credit growth and industries' output performance. If disruptions of financial intermediation 
are at the roots of creditless recoveries, their effect may be felt disproportionately more by those sectors that rely more heavily on external finance.

Based on this assumption, we estimate the following model:

$$
\text { Growth }_{s, e}=\alpha \cdot \text { Interaction }_{s, e}+\sum_{s} \beta_{s} \cdot d_{s}+\sum_{e} \beta_{e} \cdot d_{e}+\varepsilon_{s, e}
$$

where $s$ denotes the industry and $e$ identifies the recession-to-recovery episode. The $d$ 's denote dummy variables. The variable $d_{s}$ stands for the sector dummy and it is likely to incorporate technological characteristics that may affect the growth of different industries in times of crisis. The dummy $d_{e}$ identifies the single episodes detected at the country level and thus incorporates all those specific features that may characterize each crisis event. Among others, it captures the different GDP growth rates of the country between the pre-crisis peak and the full-recovery year of each episode.

Growt $_{s, e}$ is the real growth in sectoral value added over the peak-to-recovery period in sector $s$ during episode $e$. Finally, Interaction Is,$e$ is obtained multiplying CreditlessMeasure $_{e}$ by SectorCharacteristic . CreditlessMeasure $_{e}$ is the measure that we adopt to evaluate whether a recovery is creditless or not. It can be a dummy or a continuous variable. SectorCharacteristic s $_{s}$ is the dependence on external finance or an alternative sector-level variable such as tangibility, capital intensity or the relative use of trade credit.

The first measure of dependence on external finance that we use is the one obtained at the sectoral level in RZ. This is defined as capital expenditures minus cash flow from operations divided by capital expenditures, i.e. the flow of investments financed outside of retained earnings. According to RZ, there are technological reasons why some sectors depend more than others on external finance, regardless of the country. External dependence is determined by technological factors, such as production time, project scale, gestation period, capital intensity, and the importance of R\&D investment. ${ }^{8}$ RZ identify the external financial dependence at the sectoral level within a benchmark country with developed capital markets, the United States, in which firms are assumed not to face frictions in their access to financing. If a sector in the benchmark country has certain inherent characteristics, those same characteristics will remain valid in all the other countries of the sample analyzed. While the absolute value of the index may vary across countries and time, for the methodology to work it is sufficient that the industry ranking remains broadly the same in each country. ${ }^{9}$

The alternative measures for SectorCharacteristic S $_{\text {are }}$ also obtained from existing literature: Cash Conversion Cycle from Raddatz (2006); Tangibility and Capital Intensity from Braun (2002); Short-Term Debt to Trade Credit from Raddatz (2010). All these measures are assumed to be constant across countries and years, since they only depends on technological characteristics of each sector.

\footnotetext{
8 The same assumption has been extensively employed in subsequent literature, such as Braun and Larrain (2005), Kroszner et al (2007), Dell'Ariccia et al (2008) and Abiad et al (2011). In contrast, Furstenberg and Kalckreuth (2006) question it, while Fisman and Love (2007) tried to introduce a measure of growth opportunities at the sectoral level as alternative proxy of external finance dependence.

9 Rajan and Zingales (1998), for example, find support for this assumption with data from Canada.
} 
CreditlessMeasure and SectorCharacteristic are omitted from the regressions, when not interacted, since they are already incorporated in the fixed effects by recession episode and by sector.

\subsection{Data sources and sample}

Value added data at the sectoral level are obtained from the UNIDO database. ${ }^{10}$ Our main sample covers a total of 28 manufacturing industries (3-digit ISIC Rev.2 level) between 1963 and 2003, thus excluding the last global financial crisis. The choice of this period is due to the availability of data. Data are deflated using Consumer Price Indexes (CPI) at the country level from the World Bank and the IMF IFS database. ${ }^{11}$ Rather than working with continuous annual data, we focus on episodes of recession and subsequent recovery.

In our sample (see Table 11 in Appendix A) the average decline in GDP per capita during the recession episodes is 2.8 percent, although there is significant crosscountry variation (the standard deviation is 3.2 percent). The average duration of the episodes is 2.88 years with standard deviation of 1.33 years. The average duration of the recovery phase (1.55 years) tends to be slightly longer than average duration of the recession phase (1.32 years). Looking at sectoral data from the UNIDO dataset, during the recession periods the median decline is 4.7 percent for real value added, 3.2 percent for real wages, 3.1 percent for employment (number of employees). During the subsequent recovery period, their median growth rates are respectively 3.8, $1.0,0.0$ percent. Finally, the real growth rate of gross fixed capital formation for the median sector is strongly negative (-10.4 percent) during the recession phase and recovers only partially $(+1.2$ percent $)$ during the recovery phase.

\subsection{Results: creditless recoveries and the dependence on external finance}

Table 6(a) shows the results for creditless recoveries when Dependence on External Finance is the relevant SectorCharacteristic. CreditlessMeasure is the difference between real per capita credit in the recovery year and the peak year (in the Calvo sense), or the difference between annual change of real credit per capita in the recovery year and the peak year (in the Biggs sense). The sign is reversed, so that credit decreases (i.e. the creditless cases) are represented by positive values. Accordingly, we define this continuous measure as credit weakness of the peak-to-recovery episode. We expect the coefficient on the interaction term to be negative. Indeed, worsening credit conditions should have a smaller impact in industries that primarily finance their investments with internal funds than in industries that rely more heavily on external funds. A negative coefficient would confirm that internal and external funds are not perfect substitutes, supporting the view on the presence of significant

\footnotetext{
10 United Nations Industrial Development Organization. Industrial Statistics Database at the 3-Digit Level of ISIC Code, Revision 2 (2006).

11 When CPI data are missing, we use the Wholesale Price Index (WPI) in order to complete our time series.
} 
financial market imperfections. Standard errors in all the regressions are clustered by recession episode so that t-statistics are robust to correlation between errors within each episode. ${ }^{12}$

Recall that one of our main objectives is to understand whether reallocation takes place among different industries when the stock (or the flow) of bank credit at the end of a recovery phase is lower than at the beginning of the crisis. Table 6(a) suggests that sectors that are more dependent on external finance suffer the most during creditless recoveries, and this holds only for emerging markets. ${ }^{13}$

To get a sense of the magnitude of this effect, we can measure the differential in real growth rate across industries within the different kinds of recovery episodes. This differential effect measures how much faster an industry at the 75th percentile level of the SectorCharacteristic grows with respect to an industry at the 25th percentile level when we have a recession episode at the 75th percentile of the CreditlessMeasure rather than one at the 25th percentile. As for the SectorCharacteristic, the 75th percentile (industries that are highly dependent on external finance) stands between Textiles and Miscellaneous Petroleum and Coal Products, while the 25th percentile (low dependence industries) stands between Other Non-Metallic Mineral Products and Petroleum refineries. Let us apply the calculation within the EM subsample. At the 75th percentile of the CreditlessMeasure distribution (the creditless case) the annual growth rate of real credit per capita from peak to recovery is almost zero, while at the 25 th percentile (the with-credit case), the real credit per capita increases by 22.3 percentage points. According to our estimations, the differential in the growth rate amounts to -2.3 percentage points. Therefore, the redistributive effects of creditless recoveries are not only statistically significant, but also economically meaningful. Interestingly, when considering Biggs-type creditless recoveries the differential effect is also quantitatively stronger ( -5.5 percentage points) than in Calvo-type creditless recoveries.

This is not inconsistent with the theory. In fact, the dependence on external financing $a$ la RZ refers to the fraction of capital expenditures that is not financed from cash flow. However, the type of bank credit that finances capital expenditure is typically inter-temporal rather than intra-period. Therefore, when relying on the external finance dependence as the SectorCharacteristic one should expect that the dynamics of credit flows have a more important role than the dynamics of credit stocks. Not only creditless recoveries à la Biggs can occur, but they also have relevant redistributive effects among industries.

(Insert Table 6 here)

\footnotetext{
12 Reported results are obtained after identifying influential observations and removing extreme outliers from the regressions. All relevant conclusions are confirmed when we do not exclude outliers.

13 These conclusions are confirmed when we measure credit performance with a dummy variable to distinguish creditless recoveries. Results are available upon request from the authors.
} 
4.5 Results: creditless recoveries and the liquidity needs

The dependence on external finance à la RZ only refers to fixed capital expenditures and thus excludes working capital. While capital expenditures are essential for growth opportunities in the medium term, it is conceivable that working capital plays a more important role in the short term. Therefore, the measure of external dependence adopted in RZ might not be necessarily the best exogenous characteristic to consider when we look at recoveries from recession episodes, although it has been the most commonly used variable in the literature on long-run growth. In this section we consider a measure of short-term dependence on external finance, such as the sectoral liquidity needs introduced in Raddatz (2006). In particular, liquidity needs at the industry level are represented by a measure of Cash Conversion Cycle.

Table 6(b) suggests that, in the subsample of EM, the coefficient on Interaction is negative and significant, but only when considering Biggs-type creditless recoveries. However, in this case, the differential effect is even stronger (-11.6 percentage points) than in Table 6(a).

4.6 Results: creditless recoveries and collateral availability

Firms ability to access bank loans during the recovery may be affected by their ability to pledge collateral for the loan. This collateral can be captured by indicators such as Tangibility and CapitalIntensity. Tables 6(c) and 6(d) show the results obtained using these measures as SectorCharacteristic variables instead of external dependence. Creditless recoveries in the Calvo sense and in the Biggs sense are identified through the continuous version of CreditlessMeasure.

According to Braun (2002), Tangibility is the ability of assets to serve the role of securing access to external finance under an incomplete contractual setting. The level of Tangibility for each sector is proxied by the ratio of net property, plant and equipment over total assets. The higher the level of Tangibility, the lower the degree of exposure of a given sector to the agency issue. If sectors with lower Tangibility perform relatively worse when recoveries are creditless, this would indicate that a process of reallocation takes place from sectors that have difficult access to bank credit to sectors that have easy access to bank credit (i.e. high Tangibility). This would be a clear consequence of financial frictions affecting this type of crisis events. Table 6(c) shows that for EM the coefficient on the interaction term is positive as expected, both in the Calvo case and the Biggs case. The relevance of the interaction term within the EM subsample is high, with the differential effect amounting now to about 12 percentage points. Tangibility is likely to capture industries' accessibility to inter-period and intra-period bank credit, thus affecting the ability of industries to finance both fixed and operating capital in periods of higher and sustained financial frictions.

Industries also vary in terms of the intensity with which they use alternative productive resources. In Table 6(d) we adopt CapitalIntensity of each industry, i.e. the capital intensity of production, as the SectorCharacteristic, taken from Braun (2002). The sign of the coefficient for the interaction is expected to be positive. This ex- 
pectation comes from two arguments, one reinforcing the other. First, Tangibility and CapitalIntensity are positively correlated (correlation is higher than 0.8) and the ranking of the industries with respect to these characteristics do not differ too much. Sectors that use more intensively physical capital are also characterized by higher tangibility of assets and, therefore, lower financing constraints. Second, when credit supply is scarce, high physical-capital-intensive industries are likely to take advantage of the already existing physical capital to support the production, and to use it as possible collateral for financing working capital. In summary, the existing stock of physical capital is both a buffer in production and a potential source of collateral for working capital credit.

As shown in Table 6(d), the coefficient on Interaction is positive as expected, and it is significantly different from zero in EM for Biggs-type creditless recoveries.

\subsection{Results: creditless recoveries and the relevance of trade credit}

A key question is whether, during prolonged periods of tight bank credit, firms are able to substitute bank credit with alternative sources of financing. In the presence of credit market imperfections, other sources of external finance such as bond and equity issuance are not perfect substitutes for bank loans. In addition, conditions are most likely to be strained in bond and equity markets following downturns, as agency problems worsen in those markets too. Trade credit may be a better viable alternative to bank credit and other forms of market-based external finance. Therefore, we investigate whether industries that rely more on bank credit relative to trade credit experience slower output recovery.

We use data from Raddatz (2010) on the ratio of short-term debt to payables at the country and industry level as an indicator of dependence on bank intermediaries relative to trade credit as sources of short-term financing. A low value for this ratio (henceforth the Raddatz Indicator) indicates that a larger part of short term financing is obtained from trade credit. The median ratio of bank credit to trade credit at the industry (country) level is 0.89 (1.00), which indicates the high relevance of trade credit. Table 7 below summarizes the median rate of real output growth by sector depending on whether the Raddatz Indicator at the industry or country level is above or below the sample median. Creditless recoveries are kept separate from recoveries with credit. As in Table 1, Calvo-type recoveries are creditless when $\Delta$ Stock is negative, while Biggs-type recoveries are creditless when $\Delta F l o w$ is negative. Again, growth rates refer to the whole peak-to-recovery period.

\section{(Insert Table 7 here)}

In general, industries that are more dependent on bank credit as opposed to trade credit seem to grow more slowly. This is the case following any type of crisis considered here. The picture looks strikingly different at the country level. In general, industries in countries that are more dependent on bank credit as opposed to trade credit seem to grow more quickly. Again, this is true across all types of crises con- 
sidered here. ${ }^{14}$ At the industry level, a higher dependence on bank credit relative to trade credit renders firms more vulnerable to credit market disruptions during the crisis. Therefore, industries that rely relatively more on alternative sources of external financing, such as trade credit, may fare better during the peak-to-recovery period. We call this effect the substitution effect. By contrast, at the country level, a higher relative dependence on bank credit appears to have a positive impact on growth during these episodes. This highlights a contagion effect of trade credit, i.e. the propagation of financial distress and bankruptcy through trade credit chains during crisis episodes. ${ }^{15}$ This is also consistent with the theoretical model in Coricelli and Roland (2010), in which a lower dependence on bank credit relative to trade credit increases the likelihood of production-chain equilibrium. When credit markets are underdeveloped and enterprise activity is financed by trade credit, shocks may induce a break-up of credit and production chains, leading to sudden and sharp economic contractions. The relative development of a banking sector can reduce the probability of such collapses and hence plays a crucial role in softening output declines and spurring recovery.

Since trade credit may play a role in explaining the creditless character of certain recovery episodes, we could expect the substitution effect to be larger during creditless recoveries. Table 8 shows the results obtained in our previous regressions when introducing the Raddatz Indicator at the industry level as SectorCharacteristic. We should expect negative values for the interaction term. Indeed, the higher the importance of intermediaries versus suppliers as credit providers, the lower the possibility to recover when financial frictions restrain bank lending. Industries that rely relatively more on bank credit are therefore at a disadvantage during creditless recoveries.

The coefficients on the interaction term are indeed negative and significant for creditless recoveries à la Biggs, while they are not significantly different from zero for creditless recoveries à la Calvo.

(Insert Table 8 here)

\section{Endogeneity and interaction term}

A concern associated with the OLS estimates is the possibility that credit weakness, the continuous measure of credit recovery, is endogenous to the dependent variable. For example, relative higher growth of sectors that typically demand more bank credit for their activity could induce a stronger recovery in credit, thus reversing the direction of causality between credit and output growth. However, the endogeneity bias is reduced for the OLS estimator when the potentially endogenous regressor (credit weakness in our case) is interacted with an exogenous covariate (SectorCharacteristic). Indeed, recent econometric work shows that the OLS estimator of the interaction term is still consistent and asymptotically normal, and standard

\footnotetext{
${ }^{14}$ The results are similar if we consider the product of the Raddatz Indicators at the country and industry level.

15 See e.g. Kiyotaki and Moore (1997), Calvo and Coricelli (1996).
} 
inference can be applied under reasonable conditions regarding higher-order dependencies in the data. ${ }^{16}$ However, it should be noted that this consistency is restricted to the coefficient on the interaction term only and not the full marginal effect of the endogenous regressor. Since the main empirical result in our specification only depends on the interaction variable, we can assign significant relevance to the OLS inference without having to resort to instrumental variables techniques. In other words, since the economic variable of interest is the interaction term, we do not necessarily have to resort to IV estimators, especially when it is particularly difficult to find suitable instruments in terms of strength and exogeneity.

Indeed, this is what we found in our IV analysis. We tried as instrument a measure that captures credit market outcomes prior to the recession episode, as is typically done in the literature on prediction of financial crises. ${ }^{17}$ Specifically, we used the interaction between SectorCharacteristic $c_{s}$ and Credit_at_Peak $k_{e}$ as an instrument for the Interaction variable, where Credit_at_Peak $k_{e}$ is the cyclical component of real credit per capita at the output peak of each specific episode $e$. The instrument is weak, and thus it induces a loss of efficiency of the IV estimator. Nevertheless, the coefficient on Interaction in our IV estimations tends to have the same sign as in OLS regressions and very often it is also higher in absolute values. However, estimates are generally statistically insignificant.

\subsection{Robustness checks}

We also investigate whether the estimated coefficients obtained in Section 4 are biased because of the omission of some significant variables, which summarize additional structural features of sectors in each country and which are possibly correlated with our interaction term. One possible control variable is the average growth of the dependent variable in sector $s$ during the three years preceding the peak of each episode $e$, hereafter indicated as Precr $_{-} g r_{s, e}$. Indeed, we should expect that in the peak-to-recovery period the relevant variable tends to increase relatively less in sectors whose growth was higher during the pre-crisis period. This may indicate that sectors showing a larger and more sustained trend during the pre-recession period are subject to some significant correction as a consequence of the crisis. If high Precr_gr reveals capacity utilization well above the long-term equilibrium, then a negative sign of the coefficient may just signal the tendency to a natural adjustment during the peak-to-recovery episode. Among other things, this variable may actually help to distinguish industries that are more pro-cyclical in the demand of their goods from industries that are less volatile.

For the sake of simplicity, we only report Table 9, which replicates the regressions in Table 6(a) with the addition of our new control variable. As expected, the coefficient on Precr_gr is negative, while the coefficient on Interaction remains essentially unchanged with respect to baseline regressions. Although not reported here, this evidence is confirmed for all the other regressions. Therefore, the inclusion of the new variable does not alter the results discussed above.

\footnotetext{
16 See, in particular, Bun and Harrison (2014).

17 See e.g. Calvo et al (2012), Schularick and Taylor (2012), Gourinchas et al (2001)
} 
(Insert Table 9 here)

Finally, for an additional robustness test of the results, we repeat our analyses with respect to a limited subsample of recession episodes, focusing on systemic crises. As shown in Appendix B, the results obtained within this limited sample are perfectly in line with the outcomes from the extended sample.

\section{Concluding Remarks}

Our main conclusions can be summarized as follows. First, we identify two types of creditless recoveries, namely episodes during which GDP per capita recovers without an increase in the credit stock (creditless recoveries in the Calvo sense) and episodes during which GDP per capita recovers without an increase in credit flows (creditless recoveries in the Biggs sense). Both types of creditless recoveries are not rare events. However, our results highlight an important difference between those two types of creditless recoveries. Creditless recoveries à la Calvo are associated with relatively larger drops in GDP per capita during the recession phase. This is consistent with arguments on the existence of a bounce-back effect among the determinants of creditless recoveries.

Second, we find that industries that are more dependent on external finance have a relatively worse performance during creditless recoveries. Interestingly, this result only applies to emerging markets. This suggests that in developed countries there are mechanisms that enable the external dependent industries to grow in spite of the lack of recovery in credit. These mechanisms may include an improved and easier substitutability among alternative sources of financing (such as the issuance of tradable bonds and equity). In addition, redistributive effects among industries are at work especially during creditless recoveries in the Biggs sense, which suggests a stronger relevance of credit flows rather than credit stocks.

However, the dependence on external financing is not the only sector characteristic that induces a reallocation of growth among different sectors during creditless recoveries. Accessibility to bank loans (Tangibility) is also relevant. The more credit supply is constrained during the recovery, the higher is the reallocation toward sectors that posses collateral associated with tangible assets, defined as intrinsic collateral in Calvo (2011).

Finally, we find that industries that are relatively more dependent on trade credit as opposed to bank credit recover more quickly. At the industry level, a higher dependence on bank credit relative to trade credit renders firms more vulnerable during the peak-to-recovery episode (substitution effect). In this case, the reallocation process would depend neither on the dependence on external finance nor on the accessibility to bank credit, but rather on the accessibility to an alternative source of financing. At the country level, by contrast, a higher relative dependence on bank credit appears to have a positive impact on growth during recoveries (contagion effect).

There is scope for further research into the role of credit in shaping economic recoveries. Although the use of industry-level data provides insights on the mechanisms behind creditless recoveries, the analysis could be further improved by using 
firm-level data, which would enable us to directly measure the exposure of firms to credit shocks. Furthermore, it would be interesting to analyze the behavior of different factors of production during creditless recoveries, distinguishing capital accumulation and employment, as well as total factor productivity changes. This line of research can also shed light on potential connections between creditless and jobless recoveries, investigated in Calvo et al (2012).

\section{A The extended sample}

Our analyses are conducted on country episodes of recession and subsequent recovery. Episodes are constructed as in Calvo, Coricelli, and Ottonello (2012). Individual and consecutive years with negative change in real GDP are classified as recession episodes at the country level. The pre-crisis peak is identified with the year displaying the maximum level of GDP per capita preceding the first GDP contraction in the recession episode, while the full output-recovery point is the year in which GDP per capita comes back to the pre-crisis peak. The trough coincides with the minimum point within the peak-to-recovery period. We trace the recession and recovery periods by splitting the crisis years in the peak-to-trough period and the trough-to-recovery period. The extended sample comprehends all countries whose data are available in the UNIDO dataset. Overall, it consists of 421 recession episodes divided into 143 countries. However, in Table 10 we only report those episodes for which we have UNIDO data available on the peak-to-recovery change in real value added by sector. Indeed, this is the most important variable for the regression analyses.

Moreover, following Calvo et al (2006a,b), we want to limit our analysis to countries that are sufficiently integrated into the world capital market. While the sample selected by Calvo et al $(2006 a, b)$ is composed of those countries that are tracked by JP Morgan to construct its global Emerging Market Bond Index (global EMBI), our sample comprises all the countries that are included in the FTSE Global Equity Indexes. Thanks to this approach, we still refer to a leading world index provider to select the sample and, at the same time, we increase the number of tracked countries with respect to Calvo et al (2006a,b).

We also rely on the FTSE Global Equity Indexes for the classification of countries, in order to distinguish Developed Countries (DM) from Emerging Markets (EM). ${ }^{18}$ We consider the FTSE classification as sufficiently affordable for our work, since it is based on a comprehensive set of variables that is presumably relevant for our analysis, such as the total stock market capitalization, the breadth and depth of market, the restrictions on foreign investment, the efficiency of market infrastructure. However, it is important to notice that the results of our regression analyses are mostly the same once we decide to recur to the World Bank classification, which is based on estimates of gross national income per capita. ${ }^{19}$

In addition, for the EM subsample we only consider recession episodes starting after 1980, in line with Calvo et al (2012) (see Appendix B below).

As a result, Table 10 only contains 113 episodes divided into 47 countries.

(Insert Table 10 here)

(Insert Table 11 here)

\footnotetext{
18 In the FTSE classification (September 2013 update), 26 countries are classified as Developed, 10 are Advanced Emerging, 12 are Secondary Emerging and 26 are Frontier.

19 In this case, Developed Countries (DM) are those included in the group of "High Income OECD members", while Emerging Markets (EM) include the "Middle Income countries" and the "High Income non-OECD members". Indeed, this subdivision does not involve significant shifts with respect to the FTSE classification.
} 


\section{B The limited (CCO) sample}

For a robustness test of the results, we also repeat our analysis with respect to a limited subsample of recession episodes, focusing on systemic crises. While the larger number of observations in the extended sample may help achieving greater precision in the estimates of parameters, this limited sample has the advantage of focusing on episodes of major disruptions in financial markets. We select the recession episodes of this subsample according to Calvo, Coricelli, and Ottonello (2012), henceforth CCO. CCO excludes two types of episodes: those related to the disintegration of the Soviet Union and those in which GDP per capita does not fully recover its pre-crisis peak before another recession episode takes place. Long run phenomena, i.e. crises with a duration more than 2 standard deviation from the mean (15 years) are also excluded from the sample. We additionally have to exclude episodes ending after 2003 because of data availability at the sectoral level.

The limited (CCO) sample consists of 73 episodes divided into 34 countries, as reported in Table 12. We use annual data for both emerging and advanced economies, whereas CCO identify recession episodes for advanced countries using quarterly data. The reason for this choice is that we only have sectoral data at the yearly frequency. All the countries classified as developed in CCO are still classified as developed according to the FTSE categorization. South Korea is the only country switching from the group of emerging countries to the group of developed countries.

(Insert Table 12 here)

Tables 13-14 show that the results obtained within this limited (CCO) sample are perfectly in line with the outcomes from the extended sample.

(Insert Table 13 here)

(Insert Table 14 here)

\section{References}

Abiad A, Dell'Ariccia G, Li B (2011) Creditless recoveries. IMF Working Papers 11/58, International Monetary Fund

Aguiar M, Gopinath G (2007) Emerging market business cycles: The cycle is the trend. Journal of Political Economy 115:69-102

Biggs M, Mayer T, Pick A (2009) Credit and economic recovery. DNB Working Papers 218, Netherlands Central Bank, Research Department

Biggs M, Mayer T, Pick A (2010) Credit and economic recovery: Demystifying Phoenix Miracles. URL http://ssrn.com/abstract=1595980

Braun M (2002) Financial contractibility and assets' hardness: Industrial composition and growth. Working paper, Harvard University

Braun M, Larrain B (2005) Finance and the business cycle: International, inter-industry evidence. Journal of Finance 60(3):1097-1128

Bun MJ, Harrison TD (2014) OLS and IV estimation of regression models including endogenous interaction terms. UvA-Econometrics Working Papers 14-02, Universiteit van Amsterdam, Dept. of Econometrics

Calvo GA (2011) The liquidity approach to bubbles, crises, jobless recovery, and involuntary unemployment. URL http://www.columbia.edu/gc2286/

Calvo GA, Coricelli F (1996) Credit market imperfections and low-output equilibria in economies in transition. In: Blejer M, Eckstein Z, Hercowitz Z, Leiderman L (eds) Financial Factors in Economic Stabilization and Growth, Cambridge: Cambridge U. Press 
Calvo GA, Loo-Kung R (2010) US recovery: A new 'phoenix miracle'? Inter-American Development Bank, Research Department Working Paper (106)

Calvo GA, Izquierdo A, Talvi E (2006a) Phoenix miracles in emerging markets: Recovering without credit from systemic financial crises. NBER Working Papers 12101, National Bureau of Economic Research, Inc

Calvo GA, Izquierdo A, Talvi E (2006b) Sudden stops and phoenix miracles in emerging markets. American Economic Review 96(2):405-410

Calvo GA, Coricelli F, Ottonello P (2012) The labor market consequences of financial crises with or without inflation: Jobless and wageless recoveries. CEPR Discussion Papers 9218, CEPR

Cerra V, Saxena SC (2008) Growth dynamics: The myth of economic recovery. American Economic Review 98(1):439-57

Claessens S, Kose MA, Terrones ME (2009) What happens during recessions, crunches and busts? Economic Policy 24:653-700

Coricelli F, Roland I (2010) Credit and recessions. Documents de travail du Centre d'Economie de la Sorbonne 10022, Universit Panthon-Sorbonne (Paris 1), Centre d'Economie de la Sorbonne

Coricelli F, Roland I (2011) How do credit conditions shape economic recoveries? CEPR Discussion Papers 8325, CEPR

Dell'Ariccia G, Detragiache E, Rajan R (2008) The real effect of banking crises. Journal of Financial Intermediation 17(1):89-112

Fisman R, Love I (2007) Financial dependence and growth revisited. Journal of the European Economic Association, MIT Press 5(2-3):470-479

Furstenberg G, Kalckreuth U (2006) Dependence on external finance: An inherent industry characteristic? Open Economies Review 17(4):541-559

Gorodnichenko Y, Schnitzer M (2013) Financial constraints and innovation: Why poor countries don't catch up. Journal of the European Economic Association 11(5):1115-1152

Gourinchas PO, Valdes R, Landerretche O (2001) Lending booms: Latin America and the World. Journal Of LACEA Economia

Kannan P (2012) Credit conditions and recoveries from financial crises. Journal of International Money and Finance 31(5):930-947

Kiyotaki N, Moore J (1997) Credit cycles. Journal of Political Economy, University of Chicago Press 105(2):211-48

Kroszner RS, Laeven L, Klingebiel D (2007) Banking crises, financial dependence, and growth. Journal of Financial Economics 84(1):187-228

Levine R (2005) Finance and growth: Theory and evidence. In: Aghion P, Durlauf S (eds) Handbook of Economic Growth, vol 1, Elsevier, chap 12, pp 865-934

Raddatz C (2006) Liquidity needs and vulnerability to financial underdevelopment. Journal of Financial Economics 80(3):677-722

Raddatz C (2010) Credit chains and sectoral comovement: Does the use of trade credit amplify sectoral shocks? The Review of Economics and Statistics 92(4):985-1003

Rajan RG, Zingales L (1998) Financial dependence and growth. American Economic Review 88(3):55986

Reinhart CM, Rogoff KS (2009) The Aftermath of Financial Crises. American Economic Review 99(2):466-72

Schularick M, Taylor AM (2012) Credit booms gone bust: Monetary policy, leverage cycles, and financial crises, 1870-2008. American Economic Review 102(2):1029-61

Takáts E, Upper C (2013) Credit and growth after financial crises. BIS Working Papers 416, Bank for International Settlements 
Table 1 Creditless recoveries by income group

\begin{tabular}{|c|c|c|c|c|c|}
\hline \multicolumn{6}{|c|}{ CALVO SENSE } \\
\hline & \multicolumn{2}{|c|}{ Creditless Recoveries } & \multicolumn{2}{|c|}{ Recoveries With Credit } & \multirow{2}{*}{$\begin{array}{c}\text { Proportion } \\
\text { of Creditless } \\
\text { Recoveries }\end{array}$} \\
\hline & $\begin{array}{l}\text { Output } \\
\text { Decline }\end{array}$ & $\Delta$ Stock & $\begin{array}{l}\text { Output } \\
\text { Decline }\end{array}$ & $\Delta$ Stock & \\
\hline Developed Countries: & $2.6 \%$ & $-10.5 \%$ & $2.0 \%$ & $18.5 \%$ & $35.8 \%$ \\
\hline Emerging Markets: & $5.0 \%$ & $-18.6 \%$ & $2.5 \%$ & $24.9 \%$ & $40.6 \%$ \\
\hline \multicolumn{6}{|c|}{ BIGGS SENSE } \\
\hline & \multicolumn{2}{|c|}{ Creditless Recoveries } & \multicolumn{2}{|c|}{ Recoveries With Credit } & Proportion \\
\hline & $\begin{array}{l}\text { Output } \\
\text { Decline }\end{array}$ & $\Delta$ Flow & $\begin{array}{l}\text { Output } \\
\text { Decline }\end{array}$ & $\Delta$ Flow & $\begin{array}{c}\text { of Creditless } \\
\text { Recoveries }\end{array}$ \\
\hline Developed Countries: & $2.4 \%$ & -14.4 p.p. & $1.9 \%$ & 10.5 p.p. & $53.1 \%$ \\
\hline Emerging Markets: & $3.4 \%$ & -15.4 p.p. & $3.4 \%$ & 13.8 p.p. & $55.9 \%$ \\
\hline
\end{tabular}

Note: Output Decline $=$ Average decline in GDP per capita during the recession period $\Delta$ Stock $=$ Change in credit per capita between the pre-crisis peak and the full-recovery year $\Delta F$ low $=$ Change in the growth rate of credit per capita between the pre-crisis peak and the full-recovery year (expressed in percentage points)

Table 2 Characteristics of the recession episodes in the aftermath of the global financial crisis

\begin{tabular}{l}
$\begin{array}{l}\text { Recession } \\
\text { Episodes }\end{array}$ \\
\cline { 5 - 6 }
\end{tabular}


Table 3 Creditless recoveries in the aftermath of the global financial crises

\begin{tabular}{|c|c|c|c|c|c|}
\hline \multicolumn{6}{|c|}{ CALVO SENSE } \\
\hline & \multicolumn{2}{|c|}{ Creditless Recoveries } & \multicolumn{2}{|c|}{ Recoveries With Credit } & \multirow{2}{*}{$\begin{array}{c}\text { Proportion } \\
\text { of Creditless } \\
\text { Recoveries }\end{array}$} \\
\hline & $\begin{array}{l}\text { Output } \\
\text { Decline }\end{array}$ & $\Delta$ Stock & $\begin{array}{l}\text { Output } \\
\text { Decline }\end{array}$ & $\Delta$ Stock & \\
\hline Developed Countries: & $3.8 \%$ & $-7.3 \%$ & $4.0 \%$ & $14.2 \%$ & $33.3 \%$ \\
\hline Emerging Markets: & $5.0 \%$ & $-12.6 \%$ & $3.4 \%$ & $15.9 \%$ & $23.8 \%$ \\
\hline \multicolumn{6}{|c|}{ BIGGS SENSE } \\
\hline & \multicolumn{2}{|c|}{ Creditless Recoveries } & \multicolumn{2}{|c|}{ Recoveries With Credit } & Proportion \\
\hline & $\begin{array}{l}\text { Output } \\
\text { Decline }\end{array}$ & $\Delta$ Flow & $\begin{array}{l}\text { Output } \\
\text { Decline }\end{array}$ & $\Delta$ Flow & $\begin{array}{l}\text { of Creditless } \\
\text { Recoveries }\end{array}$ \\
\hline Developed Countries: & $4.8 \%$ & -4.3 p.p. & $3.5 \%$ & 6.7 p.p. & $33.3 \%$ \\
\hline Emerging Markets: & $4.4 \%$ & -15.1 p.p. & $2.9 \%$ & 8.7 p.p. & $61.9 \%$ \\
\hline
\end{tabular}

Note: Output Decline $=$ Average decline in GDP per capita during the recession period. $\Delta$ Stock $=$ Change in credit per capita between the pre-crisis peak and the full-recovery year $\Delta$ Flow $=$ Change in the growth rate of credit per capita between the pre-crisis peak and the full-recovery year (expressed in percentage points)

Table 4 Characteristics of recoveries following banking crises

\begin{tabular}{|c|c|c|c|c|c|c|}
\hline & \multicolumn{3}{|c|}{ Banking Crises } & \multicolumn{3}{|c|}{ Other Episodes } \\
\hline & $\begin{array}{l}\text { Output } \\
\text { Decline }\end{array}$ & $\Delta$ Stock & $\Delta$ Flow & $\begin{array}{l}\text { Output } \\
\text { Decline }\end{array}$ & $\Delta$ Stock & $\Delta$ Flow \\
\hline Developed Countries: & $2.7 \%$ & $1.9 \%$ & -7.6 p.p. & $2.0 \%$ & $8.9 \%$ & -0.4 p.p. \\
\hline Emerging Markets: & $6.1 \%$ & $-8.5 \%$ & -6.8 p.p. & $2.4 \%$ & $23.8 \%$ & 4.4 p.p. \\
\hline
\end{tabular}

Note: Output Decline = Average decline in GDP per capita during the recession period. $\Delta$ Stock $=$ Change in credit per capita between the pre-crisis peak and the full-recovery year $\Delta$ Flow $=$ Change in the growth rate of credit per capita between the pre-crisis peak and the full-recovery year (expressed in percentage points) 
Table 5 Reallocation effects: Synthetic country-level indicators

\begin{tabular}{|c|c|c|c|c|}
\hline \multicolumn{5}{|c|}{ DEPENDENCE ON EXTERNAL FINANCE } \\
\hline \multirow[t]{2}{*}{ Calvo-type: } & \multicolumn{2}{|c|}{ Creditless Recoveries } & \multicolumn{2}{|c|}{ Recoveries With Credit } \\
\hline & Peak Year & Recovery Year & Peak Year & Recovery Year \\
\hline Developed Countries: & 0.296 & 0.300 & 0.289 & 0.291 \\
\hline Emerging Markets: & 0.182 & 0.171 & 0.198 & 0.205 \\
\hline \multirow[t]{2}{*}{ Biggs-type: } & \multicolumn{2}{|c|}{ Creditless Recoveries } & \multicolumn{2}{|c|}{ Recoveries With Credit } \\
\hline & Peak Year & Recovery Year & Peak Year & Recovery Year \\
\hline Developed Countries: & 0.290 & 0.293 & 0.292 & 0.295 \\
\hline Emerging Markets: & 0.189 & 0.187 & 0.199 & 0.205 \\
\hline \multicolumn{5}{|c|}{ CASH CONVERSION CYCLE } \\
\hline \multirow[t]{2}{*}{ Calvo-type: } & \multicolumn{2}{|c|}{ Creditless Recoveries } & \multicolumn{2}{|c|}{ Recoveries With Credit } \\
\hline & Peak Year & Recovery Year & Peak Year & Recovery Year \\
\hline Developed Countries: & 0.999 & 1.001 & 1.006 & 1.004 \\
\hline Emerging Markets: & 0.900 & 0.871 & 0.948 & 0.955 \\
\hline \multirow[t]{2}{*}{ Biggs-type: } & \multicolumn{2}{|c|}{ Creditless Recoveries } & \multicolumn{2}{|c|}{ Recoveries With Credit } \\
\hline & Peak Year & Recovery Year & Peak Year & Recovery Year \\
\hline Developed Countries: & 1.004 & 1.005 & 1.004 & 1.001 \\
\hline Emerging Markets: & 0.947 & 0.942 & 0.922 & 0.923 \\
\hline \multicolumn{5}{|c|}{ TANGIBILITY } \\
\hline \multirow[t]{2}{*}{ Calvo-type: } & \multicolumn{2}{|c|}{ Creditless Recoveries } & \multicolumn{2}{|c|}{ Recoveries With Credit } \\
\hline & Peak Year & Recovery Year & Peak Year & Recovery Year \\
\hline Developed Countries: & 0.312 & 0.309 & 0.311 & 0.310 \\
\hline Emerging Markets: & 0.343 & 0.359 & 0.331 & 0.327 \\
\hline \multirow[t]{2}{*}{ Biggs-type: } & \multicolumn{2}{|c|}{ Creditless Recoveries } & \multicolumn{2}{|c|}{ Recoveries With Credit } \\
\hline & Peak Year & Recovery Year & Peak Year & Recovery Year \\
\hline Developed Countries: & 0.311 & 0.309 & 0.311 & 0.310 \\
\hline Emerging Markets: & 0.322 & 0.325 & 0.347 & 0.347 \\
\hline \multicolumn{5}{|c|}{ SHORT-TERM DEBT TO TRADE CREDIT } \\
\hline \multirow[t]{2}{*}{ Calvo-type: } & \multicolumn{2}{|c|}{ Creditless Recoveries } & \multicolumn{2}{|c|}{ Recoveries With Credit } \\
\hline & Peak Year & Recovery Year & Peak Year & Recovery Year \\
\hline Developed Countries: & 0.899 & 0.900 & 0.915 & 0.914 \\
\hline Emerging Markets: & 0.851 & 0.836 & 0.894 & 0.899 \\
\hline \multirow[t]{2}{*}{ Biggs-type: } & \multicolumn{2}{|c|}{ Creditless Recoveries } & \multicolumn{2}{|c|}{ Recoveries With Credit } \\
\hline & Peak Year & Recovery Year & Peak Year & Recovery Year \\
\hline Developed Countries: & 0.907 & 0.906 & 0.913 & 0.912 \\
\hline Emerging Markets: & 0.930 & 0.928 & 0.830 & 0.832 \\
\hline
\end{tabular}

Sources for sector characteristics:
(a) Rajan and Zingales (1998) for Dependence on External Finance
(b) Raddatz (2006) for Cash Conversion Cycle
(c) Braun (2002) for Tangibility
(d) Raddatz (2010) for Short-Term Debt to Trade Credit 
Table 6 Creditless recoveries and alternative SectorCharacteristic variables

\begin{tabular}{|c|c|c|c|c|c|c|}
\hline \multicolumn{7}{|c|}{ (a) Creditless recoveries and Dependence on External Finance } \\
\hline Dep:VA & \multicolumn{3}{|c|}{ Calvo sense } & \multicolumn{3}{|c|}{ Biggs sense } \\
\hline Sample & Full & DC & EM & Full & DC & EM \\
\hline Interaction & $\begin{array}{c}-0.0942 \\
{[0.113]}\end{array}$ & $\begin{array}{l}0.1046 \\
{[0.110]}\end{array}$ & $\begin{array}{c}-0.3307 * * \\
{[0.145]}\end{array}$ & $\begin{array}{c}-0.2010 \\
{[0.196]}\end{array}$ & $\begin{array}{c}0.0643 \\
{[0.097]}\end{array}$ & $\begin{array}{c}-0.8425 * * * \\
{[0.264]}\end{array}$ \\
\hline $\begin{array}{l}\mathrm{N} \\
\mathrm{r} 2 \\
\text { Diff. }\end{array}$ & $\begin{array}{c}2859 \\
0.19 \\
-0.55 \%\end{array}$ & $\begin{array}{c}1986 \\
0.21 \\
0.50 \%\end{array}$ & $\begin{array}{c}873 \\
0.19 \\
-2.33 \%\end{array}$ & $\begin{array}{c}2859 \\
0.19 \\
-0.90 \%\end{array}$ & $\begin{array}{c}1986 \\
0.21 \\
0.27 \%\end{array}$ & $\begin{array}{c}873 \\
0.19 \\
-5.53 \%\end{array}$ \\
\hline \multicolumn{7}{|c|}{ (b) Creditless recoveries and Cash Conversion Cycle } \\
\hline Dep:VA & \multicolumn{3}{|c|}{ Calvo sense } & \multicolumn{3}{|c|}{ Biggs sense } \\
\hline Sample & Full & DC & EM & Full & DC & EM \\
\hline Interaction & $\begin{array}{c}-0.0828 \\
{[0.097]}\end{array}$ & $\begin{array}{c}0.1311 \\
{[0.098]}\end{array}$ & $\begin{array}{l}-0.3604 \\
{[0.295]}\end{array}$ & $\begin{array}{c}-0.3168 \\
{[0.194]}\end{array}$ & $\begin{array}{r}-0.0283 \\
{[0.058]}\end{array}$ & $\begin{array}{c}-1.1837 * * \\
{[0.469]}\end{array}$ \\
\hline $\begin{array}{l}\mathrm{N} \\
\mathrm{r} 2 \\
\text { Diff. }\end{array}$ & $\begin{array}{c}2859 \\
0.19 \\
-0.72 \%\end{array}$ & $\begin{array}{c}1986 \\
0.21 \\
0.94 \%\end{array}$ & $\begin{array}{c}873 \\
0.19 \\
-3.79 \%\end{array}$ & $\begin{array}{c}2859 \\
0.19 \\
-2.12 \%\end{array}$ & $\begin{array}{c}1986 \\
0.21 \\
-0.18 \%\end{array}$ & $\begin{array}{c}873 \\
0.20 \\
-11.60 \%\end{array}$ \\
\hline
\end{tabular}

(c) Creditless recoveries and Tangibility

\begin{tabular}{|c|c|c|c|c|c|c|}
\hline \multirow{2}{*}{$\begin{array}{l}\text { Dep:VA } \\
\text { Sample }\end{array}$} & \multicolumn{3}{|c|}{ Calvo sense } & \multicolumn{3}{|c|}{ Biggs sense } \\
\hline & Full & DC & EM & Full & DC & EM \\
\hline Interaction & $\begin{array}{c}0.4043 \\
{[0.287]}\end{array}$ & $\begin{array}{c}-0.1364 \\
{[0.111]}\end{array}$ & $\begin{array}{l}1.1699 * \\
{[0.679]}\end{array}$ & $\begin{array}{c}0.6021 \\
{[0.548]}\end{array}$ & $\begin{array}{c}-0.1843 \\
{[0.194]}\end{array}$ & $\begin{array}{c}3.1085^{* * *} \\
{[1.243]}\end{array}$ \\
\hline $\mathrm{N}$ & 2859 & 1986 & 873 & 2859 & 1986 & 873 \\
\hline $\mathrm{r} 2$ & 0.19 & 0.21 & 0.19 & 0.19 & 0.21 & 0.20 \\
\hline Diff. & $1.39 \%$ & $-0.39 \%$ & $4.88 \%$ & $1.60 \%$ & $-0.46 \%$ & $12.09 \%$ \\
\hline
\end{tabular}

(d) Creditless recoveries and Capital Intensity

\begin{tabular}{|c|c|c|c|c|c|c|}
\hline \multirow{2}{*}{$\begin{array}{l}\text { Dep:VA } \\
\text { Sample }\end{array}$} & \multicolumn{3}{|c|}{ Calvo sense } & \multicolumn{3}{|c|}{ Biggs sense } \\
\hline & Full & DC & EM & Full & DC & EM \\
\hline Interaction & $\begin{array}{c}1.3559 \\
{[1.119]}\end{array}$ & $\begin{array}{l}0.0812 \\
{[0.404]}\end{array}$ & $\begin{array}{c}3.1367 \\
{[3.258]}\end{array}$ & $\begin{array}{l}2.8081 \\
{[2.089]}\end{array}$ & $\begin{array}{c}0.2318 \\
{[0.508]}\end{array}$ & $\begin{array}{c}11.2817 * * \\
{[5.449]}\end{array}$ \\
\hline $\mathrm{N}$ & 2859 & 1986 & 873 & 2859 & 1986 & 873 \\
\hline $\mathrm{r} 2$ & 0.19 & 0.21 & 0.19 & 0.19 & 0.21 & 0.20 \\
\hline Diff. & $0.76 \%$ & $0.04 \%$ & $2.13 \%$ & $1.22 \%$ & $0.09 \%$ & $7.15 \%$ \\
\hline
\end{tabular}

Cluster-robust $\mathrm{t}$ statistics in brackets, after clustering by recession episode. The set of dummies includes fixed effects by industry and by recession episode (coefficients not reported).

CreditlessMeasure $=$ difference $(-)$ between real credit per capita in the recovery year and the peak year (in the Calvo sense) or difference (-) between annual change of real credit per capita in the recovery year and the peak year (in the Biggs sense).

SectorCharacteristic $=$ (a) Dependence on External Finance from RZ (1998); (b) Cash Conversion Cycle from Raddatz (2006); (c) Tangibility from Braun (2002); (d) Capital Intensity from Braun (2002) 
Table 7 Recovery and relative dependence on bank credit

\begin{tabular}{lccccccc}
\hline & & \multicolumn{2}{c}{ Calvo-type Recoveries } & & \multicolumn{2}{c}{ Biggs-type Recoveries } \\
\cline { 3 - 5 } \cline { 6 - 7 } & & Creditless & With-Credit & & Creditless & With-Credit \\
\cline { 3 - 4 } \cline { 6 - 7 } Raddatz indicator & $\geq 0.89$ & $-2.1 \%$ & $3.2 \%$ & & $0.4 \%$ & $2.3 \%$ \\
by SECTOR & $<0.89$ & $1.6 \%$ & $6.6 \%$ & & $4.3 \%$ & $5.3 \%$ \\
\hline Raddatz indicator & $\geq 1.00$ & $1.4 \%$ & $5.2 \%$ & & $2.4 \%$ & $5.1 \%$ \\
by COUNTRY & $<1.00$ & $-1.6 \%$ & $1.1 \%$ & & $-0.6 \%$ & $0.6 \%$ \\
\hline
\end{tabular}

For each sub-group, the cells report the median increase of real output by sector from peak year to full recovery year.

Table 8 Creditless recoveries and the role of trade credit

\begin{tabular}{|c|c|c|c|c|c|c|}
\hline \multirow{2}{*}{$\begin{array}{l}\text { Dep:VA } \\
\text { Sample }\end{array}$} & \multicolumn{3}{|c|}{ Calvo sense } & \multicolumn{3}{|c|}{ Biggs sense } \\
\hline & Full & DC & EM & Full & DC & EM \\
\hline Interaction & $\begin{array}{l}-0.0783 \\
{[0.094]}\end{array}$ & $\begin{array}{l}-0.0079 \\
{[0.028]}\end{array}$ & $\begin{array}{c}-0.1066 \\
{[0.261]}\end{array}$ & $\begin{array}{c}-0.2702 * \\
{[0.150]}\end{array}$ & $\begin{array}{r}-0.1239 \\
{[0.116]}\end{array}$ & $\begin{array}{c}-0.6887 * \\
{[0.361]}\end{array}$ \\
\hline $\mathrm{N}$ & 2859 & 1986 & 873 & 2859 & 1986 & 873 \\
\hline $\mathrm{r} 2$ & 0.19 & 0.21 & 0.19 & 0.19 & 0.21 & 0.19 \\
\hline Diff. & $-0.64 \%$ & $-0.05 \%$ & $-1.06 \%$ & $-1.71 \%$ & $-0.74 \%$ & $-6.39 \%$ \\
\hline
\end{tabular}

$* p<0.1, * * p<0.05, * * * p<0.01$

Cluster-robust $\mathrm{t}$ statistics in brackets, after clustering by recession episode. The set of dummies includes fixed effects by industry and by recession episode (coefficients not reported). CreditlessMeasure $=$ difference $(-)$ between real credit per capita in the recovery year and the peak year (in the Calvo sense) or difference (-) between annual change of real credit per capita in the recovery year and the peak year (in the Biggs sense). SectorCharacteristic $=$ Short-Term Debt to Trade Credit from Raddatz (2010)

Table 9 Dependence on External Finance and inclusion of control variables

\begin{tabular}{|c|c|c|c|c|c|c|}
\hline \multirow{2}{*}{$\begin{array}{l}\text { Dep:VA } \\
\text { Sample }\end{array}$} & \multicolumn{3}{|c|}{ Calvo sense } & \multicolumn{3}{|c|}{ Biggs sense } \\
\hline & Full & DC & EM & Full & DC & EM \\
\hline Interaction & $\begin{array}{l}-0.0600 \\
{[0.117]}\end{array}$ & $\begin{array}{l}0.1129 \\
{[0.111]}\end{array}$ & $\begin{array}{c}-0.3286^{* *} \\
{[0.157]}\end{array}$ & $\begin{array}{l}-0.1630 \\
{[0.197]}\end{array}$ & $\begin{array}{l}0.0753 \\
{[0.099]}\end{array}$ & $\begin{array}{c}-0.8703 * * * \\
{[0.244]}\end{array}$ \\
\hline Precr_gr & $\begin{array}{l}-0.2110 \\
{[0.139]}\end{array}$ & $\begin{array}{c}-0.0434 * * \\
{[0.020]}\end{array}$ & $\begin{array}{c}-0.7445 * * * \\
{[0.176]}\end{array}$ & $\begin{array}{l}-0.2093 \\
{[0.139]}\end{array}$ & $\begin{array}{c}-0.0416^{* * *} \\
{[0.019]}\end{array}$ & $\begin{array}{c}-0.7424 * * * \\
{[0.172]}\end{array}$ \\
\hline $\mathrm{N}$ & 2746 & 1984 & 762 & 2746 & 1984 & 762 \\
\hline $\mathrm{r} 2$ & 0.18 & 0.21 & 0.20 & 0.18 & 0.21 & 0.21 \\
\hline Diff. & $-0.35 \%$ & $0.55 \%$ & $-2.15 \%$ & $-0.73 \%$ & $0.32 \%$ & $-5.17 \%$ \\
\hline
\end{tabular}

$* p<0.1, * * p<0.05, * * * p<0.01$

Cluster-robust $\mathrm{t}$ statistics in brackets, after clustering by recession episode. The set of dummies includes fixed effects by industry and by recession episode (coefficients not reported). CreditlessMeasure $=$ difference (-) between real credit per capita in the recovery year and the peak year (in the Calvo sense) or difference (-) between annual change of real credit per capita in the recovery year and the peak year (in the Biggs sense). SectorCharacteristic $=$ Dependence on external finance from RZ(1998) 
Table 10 Extended Sample of recession episodes with available data on real VA by sector

\begin{tabular}{|c|c|c|c|}
\hline \multicolumn{4}{|c|}{ Developed Countries } \\
\hline Country & Peak-to-Recovery episodes & Country & Peak-to-Recovery episodes \\
\hline AUS & $\begin{array}{l}\text { 1974-1976, 1977-1979, 1982-1985, } \\
1990-1993\end{array}$ & IRL & $1975-1977,1982-1984,1985-1987$ \\
\hline AUT & $\begin{array}{l}\text { 1974-1976, 1977-1979, 1980-1982, } \\
1992-1994\end{array}$ & ISR & $\begin{array}{l}1972-1974,1975-1979,1981-1983, \\
1983-1985,1988-1990\end{array}$ \\
\hline BEL & 1974-1976, 1980-1982, 1992-1994 & ITA & 1974-1976, 1992-1994 \\
\hline CAN & 1974-1976, 1981-1984, 1989-1995 & JPN & 1969-1971, 1973-1976, 1992-1994 \\
\hline CHE & 1994-1997 & KOR & 1979-1981, 1997-1999 \\
\hline DEU & $1974-1976,1981-1983$ & LUX & 1966-1968, 1974-1979, 1980-1982 \\
\hline DNK & 1973-1976, 1979-1982, 1987-1989 & NLD & 1974-1976, 1980-1984 \\
\hline ESP & $\begin{array}{l}\text { 1974-1976, 1978-1980, 1980-1983, } \\
1992-1994\end{array}$ & NOR & $1981-1983,1987-1990$ \\
\hline FIN & 1976-1978, 1990-1997 & NZL & 1976-1982, 1986-1988, 1988-1994 \\
\hline FRA & 1974-1976, 1992-1994 & PRT & $1973-1978,1982-1986,1992-1995$ \\
\hline GBR & 1973-1976, 1979-1983, 1990-1993 & SGP & 1984-1986, 1997-2000, 2000-2003 \\
\hline GRC & $\begin{array}{l}\text { 1973-1976, 1986-1988, 1989-1991, } \\
1991-1996\end{array}$ & SWE & 1976-1979, 1989-1995 \\
\hline HKG & $\begin{array}{l}\text { 1984-1986, 1995-1997, 1997-2000, } \\
2000-2002\end{array}$ & USA & $\begin{array}{l}\text { 1973-1976, 1979-1981, 1981-1983, } \\
1990-1992,2000-2002\end{array}$ \\
\hline \multicolumn{4}{|c|}{ Emerging Markets } \\
\hline Country & Peak-to-Recovery episodes & Country & Peak-to-Recovery episodes \\
\hline ARG & 1994-1996 & MAR & $\begin{array}{l}\text { 1986-1988, 1994-1996, 1996-1998, } \\
1998-2001\end{array}$ \\
\hline BGD & $1987-1990$ & MEX & 1985-1991, 1994-1997 \\
\hline BGR & $1995-2000$ & MLT & $1982-1986$ \\
\hline BWA & 1992-1994, 2000-2002 & MUS & $1982-1984$ \\
\hline CHL & $1981-1987,1998-2000$ & MYS & 1984-1988, 2000-2002 \\
\hline $\mathrm{COL}$ & $1980-1985$ & PHL & $1990-1996$ \\
\hline CYP & 1990-1992, 1992-1994 & RUS & 1997-1999 \\
\hline EGY & $1990-1992$ & SRB & $1998-2002$ \\
\hline HUN & 1984-1986 & SVK & $1998-2000$ \\
\hline IDN & 1981-1983, 1990-1992 & TUR & $\begin{array}{l}\text { 1988-1990, 1990-1992, 1993-1996, } \\
1998-2000\end{array}$ \\
\hline JOR & $\begin{array}{l}\text { 1982-1984, 1984-1986, 1992-1994, } \\
1997-1999\end{array}$ & & \\
\hline
\end{tabular}


Table 11 Characteristics of the peak-to-recovery episodes in the extended sample

\begin{tabular}{|c|c|c|c|c|c|c|}
\hline & \multicolumn{2}{|c|}{ Country Level } & \multicolumn{4}{|c|}{ Sector Level } \\
\hline & GDP & Duration & VA & Wages & Employment & GFCF \\
\hline Recession phase: & $-2.8 \%$ & 1.32 & $-4.7 \%$ & $-3.2 \%$ & $-3.1 \%$ & $-10.4 \%$ \\
\hline Recovery phase: & $5.3 \%$ & 1.55 & $3.8 \%$ & $1.0 \%$ & $0.0 \%$ & $1.2 \%$ \\
\hline
\end{tabular}

Table 12 Limited Sample (CCO) of recession episodes

\begin{tabular}{|c|c|c|c|c|c|c|c|c|c|}
\hline \multicolumn{10}{|c|}{ Developed Countries } \\
\hline Country & Peak & Trough & Recovery & $\begin{array}{l}\text { Output } \\
\text { Decline }\end{array}$ & Country & Peak & Trough & Recovery & $\begin{array}{r}\text { Output } \\
\text { Decline }\end{array}$ \\
\hline AUS & 1974 & 1975 & 1976 & $0.00 \%$ & ESP & 1992 & 1993 & 1994 & $1.34 \%$ \\
\hline AUS & 1982 & 1983 & 1985 & $3.53 \%$ & FRA & 1974 & 1975 & 1976 & $1.79 \%$ \\
\hline AUS & 1990 & 1992 & 1993 & $2.38 \%$ & FRA & 1992 & 1993 & 1994 & $1.10 \%$ \\
\hline AUT & 1974 & 1975 & 1976 & $0.10 \%$ & GBR & 1973 & 1975 & 1976 & $2.19 \%$ \\
\hline AUT & 1980 & 1981 & 1982 & $0.40 \%$ & GBR & 1979 & 1981 & 1983 & $3.55 \%$ \\
\hline AUT & 1992 & 1993 & 1994 & $0.30 \%$ & GBR & 1990 & 1991 & 1993 & $1.60 \%$ \\
\hline CAN & 1981 & 1982 & 1984 & $4.02 \%$ & ITA & 1974 & 1975 & 1976 & $2.67 \%$ \\
\hline CAN & 1989 & 1992 & 1995 & $5.00 \%$ & ITA & 1992 & 1993 & 1994 & $0.91 \%$ \\
\hline CHE & 1974 & 1976 & 1980 & $8.02 \%$ & KOR & 1997 & 1998 & 1999 & $7.52 \%$ \\
\hline CHE & 1981 & 1982 & 1984 & $1.88 \%$ & SWE & 1976 & 1977 & 1979 & $1.95 \%$ \\
\hline CHE & 1990 & 1993 & 1998 & $4.26 \%$ & SWE & 1989 & 1993 & 1995 & $6.08 \%$ \\
\hline DEU & 1974 & 1975 & 1976 & $0.50 \%$ & USA & 1973 & 1975 & 1976 & $2.58 \%$ \\
\hline DEU & 1981 & 1982 & 1983 & $0.30 \%$ & USA & 1979 & 1980 & 1981 & $1.20 \%$ \\
\hline DEU & 1992 & 1993 & 1994 & $1.65 \%$ & USA & 1981 & 1982 & 1983 & $2.84 \%$ \\
\hline ESP & 1978 & 1979 & 1980 & $0.84 \%$ & USA & 1990 & 1991 & 1992 & $1.40 \%$ \\
\hline ESP & 1980 & 1981 & 1983 & $0.93 \%$ & USA & 2000 & 2001 & 2002 & $0.05 \%$ \\
\hline \multicolumn{10}{|c|}{ Emerging Markets } \\
\hline Country & Peak & Trough & Recovery & $\begin{array}{l}\text { Output } \\
\text { Decline }\end{array}$ & Country & Peak & Trough & Recovery & $\begin{array}{l}\text { Output } \\
\text { Decline }\end{array}$ \\
\hline ARG & 1987 & 1990 & 1992 & $15.72 \%$ & MEX & 1985 & 1988 & 1991 & $6.48 \%$ \\
\hline ARG & 1994 & 1995 & 1996 & $4.06 \%$ & MEX & 1994 & 1995 & 1997 & $7.59 \%$ \\
\hline BGR & 1995 & 1997 & 2000 & $9.52 \%$ & MYS & 1984 & 1986 & 1988 & $5.46 \%$ \\
\hline BRA & 1980 & 1983 & 1987 & $13.32 \%$ & MYS & 1997 & 1998 & 2002 & $9.64 \%$ \\
\hline BRA & 1987 & 1988 & 1989 & $1.96 \%$ & PAN & 1986 & 1989 & 1993 & $19.02 \%$ \\
\hline BRA & 1991 & 1992 & 1993 & $2.04 \%$ & PER & 1997 & 1999 & 2002 & $2.97 \%$ \\
\hline CHL & 1981 & 1983 & 1987 & $16.43 \%$ & PHL & 1990 & 1993 & 1996 & $5.13 \%$ \\
\hline CHL & 1998 & 1999 & 2000 & $2.02 \%$ & PHL & 1997 & 1998 & 2000 & $2.73 \%$ \\
\hline CIV & 1991 & 1994 & 1997 & $8.86 \%$ & RUS & 1997 & 1998 & 1999 & $5.04 \%$ \\
\hline DOM & 1989 & 1991 & 1993 & $8.35 \%$ & SLV & 1980 & 1986 & 1994 & $19.99 \%$ \\
\hline DZA & 1992 & 1994 & 1999 & $7.09 \%$ & THA & 1996 & 1998 & 2003 & $13.68 \%$ \\
\hline ECU & 1986 & 1987 & 1988 & $2.70 \%$ & TUN & 1981 & 1982 & 1984 & $3.07 \%$ \\
\hline ECU & 1998 & 2000 & 2003 & $7.47 \%$ & TUN & 1985 & 1986 & 1990 & $4.50 \%$ \\
\hline LBN & 1988 & 1989 & 1994 & $42.62 \%$ & TUR & 1993 & 1994 & 1996 & $6.16 \%$ \\
\hline LBN & 1998 & 2000 & 2001 & $2.90 \%$ & TUR & 1998 & 1999 & 2000 & $4.82 \%$ \\
\hline MAR & 1980 & 1981 & 1982 & $5.08 \%$ & TUR & 2000 & 2001 & 2003 & $7.06 \%$ \\
\hline MAR & 1982 & 1983 & 1985 & $2.91 \%$ & URY & 1981 & 1984 & 1992 & $21.50 \%$ \\
\hline MAR & 1986 & 1987 & 1988 & $4.60 \%$ & URY & 1994 & 1995 & 1996 & $2.16 \%$ \\
\hline MAR & 1991 & 1993 & 1994 & $8.21 \%$ & VEN & 1988 & 1989 & 1992 & $10.90 \%$ \\
\hline MAR & 1994 & 1995 & 1996 & $8.03 \%$ & VEN & 1995 & 1996 & 1997 & $2.25 \%$ \\
\hline MAR & 1996 & 1997 & 1998 & $3.64 \%$ & & & & & \\
\hline
\end{tabular}


Table 13 Creditless recoveries and alternative SectorCharacteristic variables - CCO sample

\begin{tabular}{|c|c|c|c|c|c|c|}
\hline \multicolumn{7}{|c|}{ (a) Creditless recoveries and Dependence on External Finance } \\
\hline Dep:VA & \multicolumn{3}{|c|}{ Calvo sense } & \multicolumn{3}{|c|}{ Biggs sense } \\
\hline Sample & Full & $\mathrm{DC}$ & EM & Full & DC & EM \\
\hline Interaction & $\begin{array}{c}-0.1803 * * \\
{[0.086]}\end{array}$ & $\begin{array}{c}0.1164 \\
{[0.096]}\end{array}$ & $\begin{array}{c}-0.2148 * * \\
{[0.089]}\end{array}$ & $\begin{array}{l}-0.3079 \\
{[0.203]}\end{array}$ & $\begin{array}{l}0.2493 \\
{[0.153]}\end{array}$ & $\begin{array}{c}-0.5545^{* *} \\
{[0.228]}\end{array}$ \\
\hline $\begin{array}{l}\mathrm{N} \\
\mathrm{r} 2 \\
\text { Diff. }\end{array}$ & $\begin{array}{c}1160 \\
0.35 \\
-1.34 \%\end{array}$ & $\begin{array}{c}767 \\
0.25 \\
0.53 \%\end{array}$ & $\begin{array}{c}393 \\
0.42 \\
-2.27 \%\end{array}$ & $\begin{array}{c}1160 \\
0.35 \\
-1.58 \%\end{array}$ & $\begin{array}{c}767 \\
0.25 \\
0.91 \%\end{array}$ & $\begin{array}{c}393 \\
0.43 \\
-7.36 \%\end{array}$ \\
\hline \multicolumn{7}{|c|}{ (b) Creditless recoveries and Cash Conversion Cycle } \\
\hline Dep:VA & \multicolumn{3}{|c|}{ Calvo sense } & \multicolumn{3}{|c|}{ Biggs sense } \\
\hline Sample & Full & DC & EM & Full & DC & EM \\
\hline Interaction & $\begin{array}{l}-0.0903 \\
{[0.066]} \\
\end{array}$ & $\begin{array}{c}0.1802 \\
{[0.141]} \\
\end{array}$ & $\begin{array}{c}-0.2139 * * \\
{[0.097]}\end{array}$ & $\begin{array}{c}-0.4867 * * * \\
{[0.176]}\end{array}$ & $\begin{array}{c}0.0642 \\
{[0.253]} \\
\end{array}$ & $\begin{array}{c}-0.7536 * * * \\
{[0.212]} \\
\end{array}$ \\
\hline $\begin{array}{l}\text { N } \\
\text { r2 } \\
\text { Diff. }\end{array}$ & $\begin{array}{c}1160 \\
0.35 \\
-1.00 \%\end{array}$ & $\begin{array}{c}767 \\
0.25 \\
1.22 \%\end{array}$ & $\begin{array}{c}393 \\
0.42 \\
-3.37 \%\end{array}$ & $\begin{array}{c}1160 \\
0.35 \\
-3.72 \%\end{array}$ & $\begin{array}{c}767 \\
0.24 \\
0.35 \%\end{array}$ & $\begin{array}{c}393 \\
0.43 \\
-14.93 \%\end{array}$ \\
\hline
\end{tabular}

(c) Creditless recoveries and Tangibility

\begin{tabular}{|c|c|c|c|c|c|c|}
\hline \multirow{2}{*}{$\begin{array}{l}\text { Dep:VA } \\
\text { Sample }\end{array}$} & \multicolumn{3}{|c|}{ Calvo sense } & \multicolumn{3}{|c|}{ Biggs sense } \\
\hline & Full & DC & EM & Full & DC & EM \\
\hline Interaction & $\begin{array}{c}0.3532 \\
{[0.213]}\end{array}$ & $\begin{array}{c}-0.2838 \\
{[0.366]}\end{array}$ & $\begin{array}{c}0.5833 * * \\
{[0.246]}\end{array}$ & $\begin{array}{c}1.6191 * * * \\
{[0.502]}\end{array}$ & $\begin{array}{l}0.2601 \\
{[0.673]}\end{array}$ & $\begin{array}{c}2.2322 * * * \\
{[0.497]}\end{array}$ \\
\hline $\mathrm{N}$ & 1160 & 767 & 393 & 1160 & 767 & 393 \\
\hline $\mathrm{r} 2$ & 0.36 & 0.25 & 0.43 & 0.36 & 0.25 & 0.44 \\
\hline Diff. & $1.56 \%$ & $-0.76 \%$ & $3.64 \%$ & $4.91 \%$ & $0.56 \%$ & $17.55 \%$ \\
\hline
\end{tabular}

(d) Creditless recoveries and Capital Intensity

\begin{tabular}{|c|c|c|c|c|c|c|}
\hline \multirow{2}{*}{$\begin{array}{l}\text { Dep:VA } \\
\text { Sample }\end{array}$} & \multicolumn{3}{|c|}{ Calvo sense } & \multicolumn{3}{|c|}{ Biggs sense } \\
\hline & Full & DC & EM & Full & DC & EM \\
\hline Interaction & $\begin{array}{l}0.4375 \\
{[0.822]}\end{array}$ & $\begin{array}{c}-0.0678 \\
{[1.612]}\end{array}$ & $\begin{array}{l}1.2680 \\
{[1.223]}\end{array}$ & $\begin{array}{c}5.8050^{* * * *} \\
{[2.046]}\end{array}$ & $\begin{array}{l}1.8827 \\
{[2.756]}\end{array}$ & $\begin{array}{c}7.8407 * * * \\
{[2.250]}\end{array}$ \\
\hline $\mathrm{N}$ & 1160 & 767 & 393 & 1160 & 767 & 393 \\
\hline $\mathrm{r} 2$ & 0.35 & 0.24 & 0.42 & 0.36 & 0.25 & 0.44 \\
\hline Diff. & $0.31 \%$ & $-0.03 \%$ & $1.29 \%$ & $2.87 \%$ & $0.66 \%$ & $10.04 \%$ \\
\hline
\end{tabular}

$* p<0.1, * * p<0.05$, *** $p<0.01$ Cluster-robust $t$ statistics in brackets, after clustering by recession episode. The set of dummies in-
cludes fixed effects by industry and by recession episode (coefficients not reported).

CreditlessMeasure $=$ difference $(-)$ between real credit per capita in the recovery year and the peak year (in the Calvo sense) or difference (-) between annual change of real credit per capita in the recovery year and the peak year (in the Biggs sense).

SectorCharacteristic = (a) Dependence on External Finance from RZ (1998); (b) Cash Conversion Cycle from Raddatz (2006); (c) Tangibility from Braun (2002); (d) Capital Intensity from Braun (2002) 
Table 14 Creditless recoveries and the role of trade credit: CCO sample

\begin{tabular}{|c|c|c|c|c|c|c|}
\hline \multirow{2}{*}{$\begin{array}{l}\text { Dep:VA } \\
\text { Sample }\end{array}$} & \multicolumn{3}{|c|}{ Calvo sense } & \multicolumn{3}{|c|}{ Biggs sense } \\
\hline & Full & DC & EM & Full & $\mathrm{DC}$ & EM \\
\hline Interaction & $\begin{array}{c}0.0358 \\
{[0.069]}\end{array}$ & $\begin{array}{c}0.0604 \\
{[0.083]}\end{array}$ & $\begin{array}{c}0.0114 \\
{[0.085]}\end{array}$ & $\begin{array}{c}-0.2825 * * \\
{[0.129]}\end{array}$ & $\begin{array}{c}-0.0918 \\
{[0.112]}\end{array}$ & $\begin{array}{c}-0.3575 * * \\
{[0.166]}\end{array}$ \\
\hline $\mathrm{N}$ & 1160 & 767 & 393 & 1160 & 767 & 393 \\
\hline $\mathrm{r} 2$ & 0.35 & 0.25 & 0.42 & 0.35 & 0.25 & 0.43 \\
\hline Diff. & $0.38 \%$ & $0.39 \%$ & $0.17 \%$ & $-2.04 \%$ & $-0.47 \%$ & $-6.70 \%$ \\
\hline
\end{tabular}

$* p<0.1, * * p<0.05, * * * p<0.01$

Cluster-robust $\mathrm{t}$ statistics in brackets, after clustering by recession episode. The set of dummies includes fixed effects by industry and by recession episode (coefficients not reported). CreditlessMeasure $=$ difference $(-)$ between real credit per capita in the recovery year and the peak year (in the Calvo sense) or difference (-) between annual change of real credit per capita in the recovery year and the peak year (in the Biggs sense). SectorCharacteristic $=$ Short-Term Debt to Trade Credit from Raddatz (2010) 